\title{
ВИВЧЕННЯ ВПЛИВУ ВАГОВИХ КОЕФІЦІЕНТІВ НА ПРОГНОСТИЧНУ ВАЛІДНІСТЬ КОНКУРСНОГО БАЛА ВСТУПНИКІВ ГАЛУЗІ ЗНАНЬ «ОХОРОНА ЗДОРОВ'Я»
}

\author{
() А. А. Котвіцька, Н. В. Живора, С. В. Погорєлов, І. В. Красовський, О. О. Віслоус \\ Національний фрармацевтичний університет, Харків \\ socpharm@nuph.edu.ua
}

\begin{abstract}
Мета роботи. Вивчення впливу вагових коефіцієнтів на прогностичну валідність конкурсного бала шляхом математичного обґрунтування оптимальних значень, що забезпечують максимальну валідність конкурсного відбору.

Матеріали і методи. Проведено дослідження успішності здобувачів вищої освіти першого курсу денної фрорми навчання за спеціальністю 226 «Фармація».

Оцінку сили лінійного взаємозв'язку між конкурсним балом (та його складовими) і показниками поточної успішності здобувачів вищої освіти проводили за допомогою розрахунку коефіцієнта кореляції за Пірсоном. Статистичну обробку проведено з використанням Microsoft Excel.

Результати й обговорення. У статті розглянуто можливість і допустимість використання результатів ЗНО для виявлення вступників, які зможуть успішно продовжити навчання у вищій школі. Запропоновано математично обґрунтовані рекомендації щодо підвищення якості конкурсного відбору для виявлення вступників та їх потенціалу для вивчення. Рекомендації основані на статистичному аналізі даних про успішність здобувачів вищої освіти першого курсу навчання спеціальності 226 «Фармація» галузі знань «Охорона здоров'я», що вступили до Національного фрармацевтичного університету (НФаУ) у 2015 році, в зіставленні 3 конкурсним балом. Доведено, що цілеспрямовано змінюючи вагові коесріцієнти, які використовуються при розрахунку конкурсного бала, ВН3 може позитивно впливати на якісний склад здобувачів вищої освіти. Отримано значення вагових коефріцієнтів, при яких досягається максимальна валідність конкурсного відбору.

Висновки. За результатами дослідження встановлено силу кореляційного зв'язку між конкурсним балом вступника та поточною успішністю здобувача вищої освіти під час першого та другого семестрів навчання.
\end{abstract}

Ключові слова: прогностична валідність; конкурсний бал; результати 3НО; предиктор успішності; вступник; здобувач вищої освіти.

Вступ. Одним із основних завдань державної політики в галузі освіти є рівний доступ громадян країни до вищої освіти. Введення в Україні зовнішнього незалежного оцінювання (ЗНО) результатів навчання учнів, здобутих на основі повної загальної середньої освіти та використання їх результатів при проведенні вступної кампанії до вищих навчальних закладів (ВН3) є важливим кроком у ресрормуванні української освіти за останнє десятиріччя. У системі вступу до вишів в Україні в 2007 р. відбулася радикальна реформа, яка передбачала перехід від вступних іспитів у ВН3 до запровадження 3НО, яке на сьогодні виступає головним критерієм конкурсного відбору під час вступу.

Система зовнішнього незалежного оцінювання це система стандартизованих компонентів: інструментів вимірювання - тестів, процедур проведення тестувань і перевірки виконання тестів. Така форма тестування спрямована вирішити відразу декілька важливих завдань: по-перше, забезпечення реалізації конституційних прав громадян на рівний доступ до якісної вищої освіти; по-друге, об'єктивне визначення рівня навчальних досягнень випускників загальноосвітніх навчальних закладів при їх вступі до вищих навчальних закладів [1].

Основними показниками якості системи вступу до ВНЗ на основі ЗНО є:

- валідність - показник ефрективності відбору студентів, здатних до успішного навчання у ВНЗ за певною спеціальністю;

- справедливість - відхилення успішності при вступі до ВНЗ на основі ЗНО для соціально значимих груп абітурієнтів (за гендерною ознакою, місчем проживання, типом навчального закладу та iн.);

- органічність або суспільне сприйняття - рівень громадського схвалення (випускники ЗНЗ, вчителі, здобувачі вищої освіти, викладачі).

Вивченню прогностичної валідності критеріїв відбору до ВН3 приділяється належна увага в багатьох країнах світу. Результати цих досліджень характеризують ефрективність чинних моделей відбору, визна-

ISSN 2312-0967. Pharmaceutical review. 2017. № 4 
чають напрями їх корекції та вдосконалення. Стандартизовані вступні іспити (ability tests) широко використовуються у світовій практиці. Найвідоміші 3 них - Scholastic Aptitude Test, Scholastic Assessment Test (SAT) і American College Testing (ACT) в США, Matura - в низці європейських країн [1]. Схожі процедури іспитів застосовуються також у Швеції - тест академічних здібностей Swedish Scholastic Aptitude Test (SweSAT); в Австралії - тест академічних здібностей; в Ізраїлі - психометричний тест Preliminary English Test (PET); у Грузії - тест академічних здібностей General Achievement Test (GAT); у Киргизстані - тест академічних здібностей Classics Admissions Test (CAT) тощо.

Найбільший досвід у ссрері вивчення зв'язку результатів довузівського тестування і подальшої успішності у ВНЗ накопичено в США. Дослідження в цій сорері ведуться як на державному рівні, так і на рівні окремих університетів за власними даними. Кожен ВН3 встановлює, який з тестів, SAT або ACT, приймається в якості критерію відбору. На сьогодні більшість американських ВНЗ приймає результати обох тестів, із встановленням шкали відповідності балів. Вважається, що обидва тести оцінюють як предметні знання, так і загальні здібності вступників до навчання, тобто вони одночасно виступають тестами знань і тестами здібностей $[2,3]$.

Ураховуючи результати вивчення як міжнародного досвіду, так і вітчизняного, можна стверджувати, що особливого значення набуває вивчення прогностичного значення ЗНО [1]. Одним із критеріїв правильності вибору показників конкурсного відбору, який дозволяє прогнозувати успішність навчання здобувачів вищої освіти на першому курсі ВНЗ, виступає прогностична валідність. Даний критерій являє собою кореляцію між конкурсним балом і середнім балом результатів сесій здобувачів вищої освіти на першому курсі ВН3 $[4,5]$.

Вибір конкурсних предметів та вагових коефіцієнтів фрормування конкурсного бала відіграє найважливішу роль у процедурі відбору вступників. Перелік конкурсних предметів визначає набір специфічних здібностей, знань і навичок вступників, що тестуються. Вагові коесріцієнти визначають внесок результатів тестувань з окремих предметів у підсумковий критерій. Вибір оптимального набору предметів та їх ваг може ґрунтуватися на вивченні прогностичної валідності конкурсного відбору, тобто коефріцієнта кореляції між показником, за яким здійснюється конкурсний відбір, і результатами навчання здобувача вищої освіти протягом перших семестрів навчання. У разі неоптимального вибору конкурсних предметів та їх ваг відбувається несприятливий відбір вступників.

Як свідчать результати вступних кампаній, які аналізують практично усі навчальні заклади, до ВН3 можуть потрапити такі вступники, середня успішність яких нижче за очікувану успішність вступників, що були відсіяні під час вступної кампанії через різні причини. Не викликає сумніву, що ВНЗ об'єктивно зацікавлений у відборі вступників, здатних навчатися краще. Таким чином, з точки зору ВНЗ, система конкурсного відбору буде якісною, якщо університет отримає здобувачів вищої освіти, які більш адаптовані до успішного навчання [6].

Мета роботи - вивчення впливу вагових коефіцієнтів на прогностичну валідність конкурсного бала шляхом математичного обґрунтування оптимальних значень, що забезпечують максимальну валідність конкурсного відбору.

Дослідження проводилося на основі даних про результати ЗНО, середній бал атестата, за якими фрормується конкурсний бал і середній семестровий бал за перший та другий семестри, отримані здобувачами вищої освіти у Національному фрармацевтичному університеті. Основним завданням дослідження є визначення валідності результатів ЗНО як інструменту відбору вступників до університету.

Матеріали і методи. Проведено дослідження успішності 315 здобувачів вищої освіти першого курсу денної фрорми навчання за спеціальністю 226 «Фармація», зарахованих до НФаУ у 2015 р. Відомості про бали сертифікатів 3 НО та середній бал документа про повну загальну середню освіту виражені у 200-бальній шкалі.

Оцінки поточної успішності, отримані здобувачами вищої освіти за підсумками першого та другого семестрів, виражені в 100-бальній шкалі Єдиної кредитнотрансферної системи (ЄКТС). Оцінка сили лінійного взаємозв'язку між конкурсним балом (та його складовими) і показниками поточної успішності здобувачів вищої освіти проводилась за допомогою розрахунку коефіцієнта кореляції за Пірсоном. Статистична обробка проведена з використанням Microsoft Excel.

32008 р. у НФаУ впроваджена статистична база - автоматизована система управління університетами (АСУ), що являє собою низку пов'язаних між собою програм, які забезпечують управління вузом в єдиному інформаційному просторі, і включає в себе модулі, що працюють у середовищі Windows та Webпортал. Вся інфрормація зберігається в єдиній загальній базі даних. Система включає модулі: «абітурієнт», «студент», «успішність», «документообіг», «відділ кадрів».

Такий масив даних, що включає інфрормацію про бали ЗНО, середній бал документа про освіту та поточні семестрові оцінки всіх здобувачів освіти, які вступали до НФаУ з 2008 р., дозволяє провести дослідження і оцінити кореляцію конкурсного вступного бала вступників та успішності їх подальшого навчання в університеті.

Результати й обговорення. За результатами як закордонних, так і вітчизняних досліджень, можна стверджувати, що перший курс, на якому вивчаються в основному базові дисципліни, визначає здатність

ISSN 2312-0967. Фармацевтичний часопис. 2017. № 4 
та успішність навчання на наступних курсах. Тому важливою умовою прогностичної валідності конкурсного бала $€$ його здатність передбачати успішність саме на першому курсі.

Стосовно показника академічної успішності студента за весь період навчання встановлено, що існують деякі особливості, які вимагають ретельного вивчення фракторів впливу. Так, відповідно до статистично узагальнених даних результатів досліджень, проведених у США, середня оцінка коефіцієнта кореляції між балами за вступними тестами (SAT і ACT) i показником академічної успішності студента за весь період навчання знаходиться в інтервалі від 0,35 до 0,46, що свідчить про слабкий зв'язок між досліджуваними параметрами згідно зі шкалою Чедока, та згідно з дослідженням дозволяє передбачувати лише 12-25 \% варіації оцінок у ВН3 [8, 11].

Як зазначалося раніше, однією зі складових бала для конкурсного відбору в Україні виступає значення середнього бала документа про середню освіту. Такий підхід відповідає міжнародним тенденціям, зокрема у США разом із результатами вступних випробувань SAT або ACT враховується середній бал документа про середню освіту, який достатньо часто виявляється кращим предиктором успішності у ВН3, ніж бали, отримані при зовнішньому тестуванні [9]. У подальшому спільний облік результатів вступних іспитів та середнього бала документа про середню освіту в одній моделі значно підвищує якість передбачення академічних досягнень здобувача вищої освіти [10].

Згідно з Умовами прийому до ВНЗ України, які діяли протягом 2008-2014 рр., конкурсний бал формувався за результатами 3НО, а також (з 2010 р.) середнього бала документа про середню освіту й зарахування осіб до ВНЗ передбачало вищий конкурсний бал. У 2015 р. конкурсний бал розраховувався 3 використанням вагових коефіцієнтів, які встановлює ВНЗ відповідно до Умов прийому (наказ МОН України від 15.10.2014 р. № 1172 «Про затвердження Умов прийому на навчання до вищих навчальних закладів України в 2015 році»).
Відповідно до мети дослідження щодо вивчення впливу вагових коефіцієнтів на прогностичну валідність конкурсного бала, нами застосовано лінійний регресійний аналіз, що дозволяє оцінити, яку частку дисперсії залежної змінної пояснюють змінні-предиктори, а також оцінити індивідуальний вплив кожної 3 цих змінних-предикторів на передбачувану здатність моделі.

Оцінка лінійної залежності з використанням регресійного аналізу є доцільною та адекватною 3 точки зору того, що сама система відбору вступників передбачає наявність лінійного зв'язку між конкурсним балом і здібностями вступника до подальшого навчання (рис. 1).

При прийомі до ВНЗ вступники ранжуються на підставі конкурсного балуа, і передбачається, що більш високий бал означає кращий рівень підготовки вступника [5]. Так, у 2015 р. високий бал від 170 до 180 балів складав 20 \% від загальної суми поданих заяв (рис. 2).

У 2015 р. конкурсний бал $S_{k}$ для вступників, що подали заяви на вступ до НФаУ на спеціальність «Фармація» на базі повної загальної середньої освіти, розраховувався за такою фрормулою:

$S_{k}=0,1 * S_{a m}+0,2 * S_{\text {ккр }}+0,35 * S_{\text {біол }}+0,35 * S_{\text {хім}}$,

де $\boldsymbol{S}_{\text {am }}$ - середніи бал документа про повну загальну середню освіту, $\boldsymbol{S}_{\text {укр }}$ - бал 3 НО з української мови та літератури, $\mathbf{S}_{\text {біол }}-$ бал $3 \mathrm{HO}$ з біології, $\boldsymbol{S}_{\text {хім }}-$ бал зНО 3 хімії.

Кожен здобувач вищої освіти $k$ із вибірки отримував набір оцінок ( $\left.\boldsymbol{G}_{\boldsymbol{k} \mathbf{1}}, \boldsymbol{G}_{\boldsymbol{k} \mathbf{2}}, \ldots \boldsymbol{G}_{\boldsymbol{k} n}\right)$, причому довжина набору оцінок $\boldsymbol{n}$ могла бути різною. Для загального аналізу застосовано середнє арисрметичне, яке обчислювалося за фрормулою:

$\mathbf{G}_{k}=\left(\mathbf{G}_{k 1}+\mathbf{G}_{k 2}+\ldots+\mathbf{G}_{k n}\right) / \boldsymbol{n}$.

Інтегральний показник прогностичної валідності для $\boldsymbol{m}$ здобувачів вищої освіти обчислювався як коефріцієнт кореляції між величинами $S=\left(S_{1}, S_{2}, \ldots S_{m}\right)$ та $\mathbf{G}=\left(\mathbf{G}_{1}, \mathbf{G}_{2}, \ldots . \mathbf{G}_{m}\right)$ за Пірсоном.

За результатами аналізу даних за перший семестр були отримані такі результати. Прогностична валід-

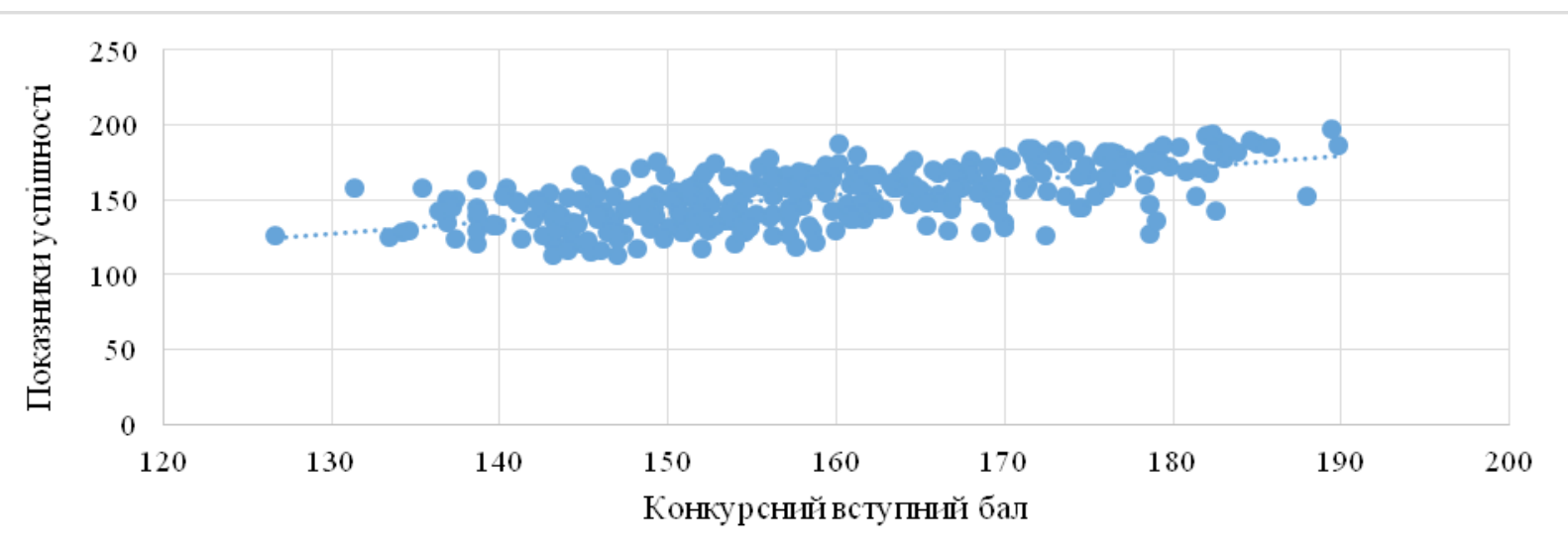

Рис. 1. Лінія регресії показників поточної успішності від конкурсного вступного бала.

ISSN 2312-0967. Pharmaceutical review. 2017. № 4 
Фармацевтична освіта Pharmaceutical education

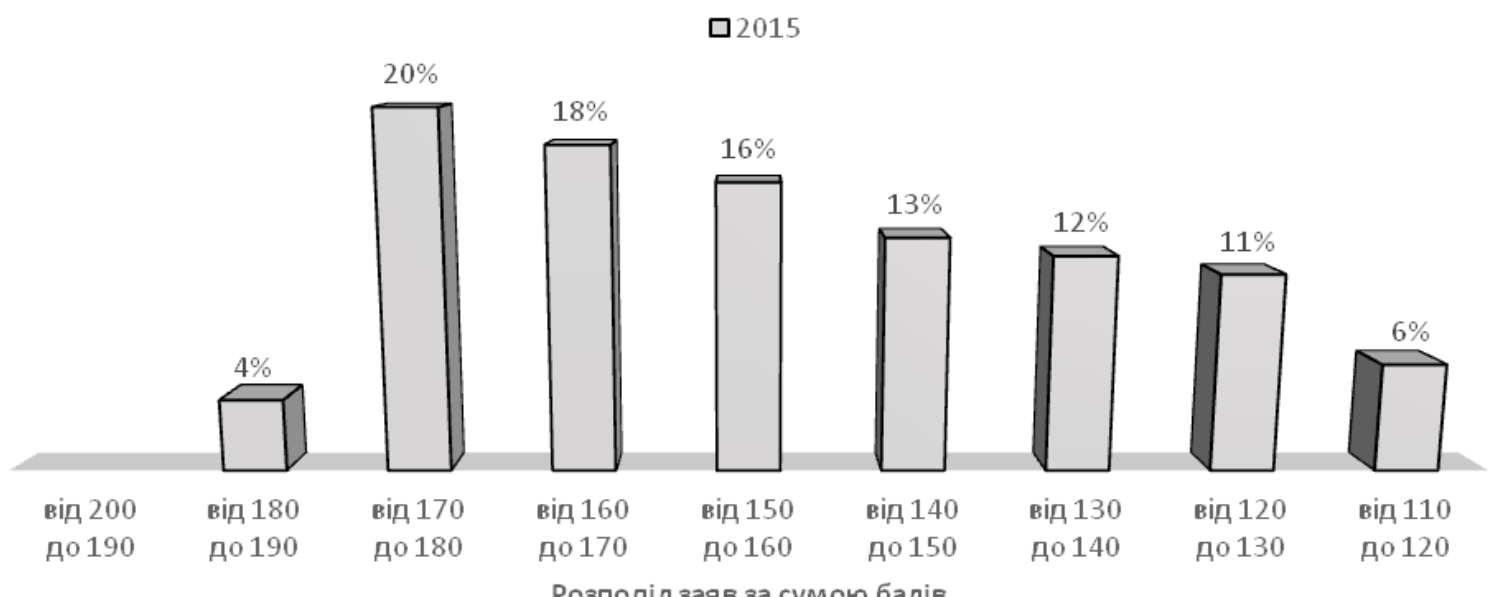

Рис. 2. Розподіл заяв за сумою балів від кількості зарахованих вступників на денну форму за спеціальністю 226 «Фармація».

ність 3 окремих профільних предметів 3НО - біології та хімії становить 0,50 та 0,52 відповідно, що визначається як достатньо високий результат, але він менший за результат 3 НО з української мови та літератури - 0,59, а також значно менший за середній бал атестата про повну загальну середню освіту - 0,63 або середній бал результатів ЗНО - 0,61.

Інтегральний показник прогностичної валідності конкурсного вступного бала, що обчислювався за формулою (1), становить 0,62. 3 урахуванням результатів дослідження, що нами отримано, можна стверджувати, що для підвищення прогностичної валідності конкурсного бала необхідним є збільшення вагових коефіцієнтів середнього бала атестата і бала $3 \mathrm{HO} 3$ української мови та літератури. Оскільки сума всіх вагових коефіцієнтів повинна дорівнювати одиниці, збільшення призведе до зменшення вагових коефріцієнтів ЗНО з фрахових дисциплін. Наприклад, якщо

$S_{k}=0,2 * S_{a m}+0,2 * S_{\text {укр }}+0,3 * S_{\text {біол }}+0,3 * S_{\text {хім }}$

то прогностична валідність буде становити 0,64.
У разі подальшого збільшення вагових коефіцієнтів, наприклад, середнього бала атестата та бала зНО з української мови, отримуємо прогностичну валідність 0,65 .

$$
S_{k}=0,25 * S_{\text {ат }}+0,25 * S_{\text {укр }}+0,25 * S_{\text {біол }}+0,25 * S_{\text {хім }}
$$

За результатами проведених розрахунків нами одержані значення коефріцієнта кореляції між поточною успішністю здобувачів вищої освіти НФаУ за семестр та складовими конкурсного бала (табл. 1).

Інтегральні показники прогностичної валідності конкурсного вступного бала, що обчислювався за фрормулами (1), (4) та (5), наведені в таблиці 2.

При подальшому збільшенні ваги середнього бала атестата та, відповідно, зменшенні ваги результатів зНО з фахових дисциплін прогностична валідність зменшується.

Як і очікувалось, кореляційний зв'язок між конкурсним балом та поточною успішністю здобувачів вищої освіти у другому семестрі є дещо меншим у порівнянні з результатами першого семестру, але залишаєть-

Таблиця 1. Коефріцієнт кореляції між поточною успішністю здобувачів вищої освіти НФаУ за перший курс та складовими конкурсного бала

\begin{tabular}{|l|c|c|c|c|c|}
\hline & $\begin{array}{c}\text { Бал 3НО } \\
\text { з біології }\end{array}$ & $\begin{array}{c}\text { Бал 3НО } \\
\text { з хімії }\end{array}$ & $\begin{array}{c}\text { Бал 3НО 3 } \\
\text { української мови та } \\
\text { літератури }\end{array}$ & $\begin{array}{c}\text { Середній бал } \\
\text { результатів 3НО }\end{array}$ & $\begin{array}{c}\text { Середній бал атестата } \\
\text { про повну загальну } \\
\text { середню освіту }\end{array}$ \\
\hline Перший семестр & 0,50 & 0,52 & 0,59 & 0,61 & 0,63 \\
\hline Другий семестр & 0,42 & 0,48 & 0,50 & 0,53 & 0,57 \\
\hline Перший курс & 0,47 & 0,49 & 0,57 & 0,58 & 0,61 \\
\hline
\end{tabular}

Таблиця 2. Коесріцієнт кореляції між показниками поточної успішності та конкурсного вступного бала для різних значень вагових коесріцієнтів

\begin{tabular}{|c|c|c|c|}
\hline & $\mathrm{S}_{\mathrm{k}}$ за фрормулою (1) & $\mathrm{S}_{\mathrm{k}}$ за фрормулою (4) & $\mathrm{S}_{\mathrm{k}}$ за срормулою (5) \\
\hline Перший семестр & 0,62 & 0,64 & 0,65 \\
\hline Другий семестр & 0,53 & 0,55 & 0,56 \\
\hline Перший курс & 0,57 & 0,62 & 0,62 \\
\hline
\end{tabular}

ISSN 2312-0967. Фармацевтичний часопис. 2017. № 4 
ся на тому ж середньому рівні сили зв'язку згідно зі шкалою Чедока, що й для першого семестру.

У цілому за підсумками аналізу прогностичної валідності результатів ЗНО з окремих предметів встановлено, що ЗНО з української мови та літератури виявляється більш значущим предиктором успішності, ніж ЗНО з профрільних предметів. Достатньо неочікуваним є результат щодо бала ЗНО з просрільних предметів, який виявився слабшим предиктором успішності. На нашу думку, основними фракторами, які визначають такі результати, є:

- зміст ЗНО з фахових дисциплін (хімія, біологія);

- наявність значно меншої кількості вступників, що складають ЗНО з профрільних предметів;

- здійснення оцінки ЗНО з профрільних предметів шляхом фрактичних знань випускників та сорормованих у школі навичок, а не загального розуміння предмета та здатності вступника до діяльності в конкретній галузі науки.

3 іншого боку, середній бал документа про повну загальну освіту вимірює здатність вступника навчатись, а отже, $є$ суттєвим предиктором успішності навчання у ВН3. Можна також зазначити, що бал $3 \mathrm{HO} з$ української мови та літератури має меншу статистичну похибку через значно більшу кількість вступників, що складають ЗНО з української мови та літератури у порівнянні з кількістю вступників, що складають інші фрахові ЗНО.

Стосовно вагових коефіцієнтів у формулі підрахунку конкурсного вступного бала, нами математично обґрунтовано, що максимальна прогностична валідність досягається в такому випадку, коли всі чотири оцінки (три оцінки ЗНО та середній бал атестата) будуть враховуватись 3 однаковим ваговим коефіці- єнтом, який дорівнює 0,25. Таке твердження пояснюється тим, що два результати ЗНО 3 профрільних предметів вимірюють фрактичні знання вступників у специфічних галузях науки (хімія та біологія), а результат ЗНО з української мови та літератури і середній бал документа про повну загальну середню освіту вимірюють загальний рівень здібностей вступника та його здатність навчатись.

Висновки. 1. Вивчено вплив вагових коефіцієнтів на прогностичну валідність конкурсного бала шляхом математичного обґрунтування оптимальних значень, що забезпечують максимальну валідність конкурсного відбору.

2. У ході проведеного дослідження оцінено здатність ЗНО визначати подальшу академічну успішність здобувачів вищої освіти, які навчаються за спеціальністю 226 «Фармація» галузі знань «Охорони здоров'я». Результати дослідження свідчать, що середній бал ЗНО є прийнятним для того, щоб визнати його дійсним інструментом відбору вступників.

3. Математично обґрунтовано доцільність зміни вагових коефріцієнтів, що використовуються для розрахунку вступного конкурсного бала, для підвищення валідності відбору якісного складу здобувачів вищої освіти. Максимальна валідність досягається при однакових вагових коефіцієнтах усіх складових.

4. Встановлено, що найбільша кореляційна залежність спостерігається між конкурсним балом та поточною успішністю здобувачів вищої освіти під час першого семестру навчання, що надає можливість стверджувати про важливу роль університетської освіти та її вплив на рівень успішності здобувачів вищої освіти.

\title{
ИЗУЧЕНИЕ ВЛИЯНИЯ ВЕСОВЫХ КОЭФФИЦИЕНТОВ НА ПРОГНОСТИЧЕСКУЮ ВАЛИДНОСТЬ КОНКУРСНОГО БАЛЛА ПОСТУПАЮЩЕГО В ОБЛАСТИ ЗНАНИЙ «ЗДРАВООХРАНЕНИЕ»
}

\author{
А. А. Котвицкая, Н. В. Живора, С. В. Погорелов, И. В. Красовский, О. А. Вислоус \\ Национальный фрармацевтический университет, Харьков \\ socpharm@nuph.edu.ua
}

Цель работы. Изучение влияния весовых коэффрициентов на прогностическую валидность конкурсного балла путем математического обоснования с последующим определением их оптимальных значений, что обеспечивает максимальную валидность конкурсного отбора.

Материалы и методы. Проведено исследование успешности соискателей высшего образования первого курса дневной формы обучения по специальности 226 «Фармация».

Оценка силы линейной взаимосвязи между конкурсным баллом (и его составляющими) и показателями текущей успеваемости соискателей высшего образования проводилась с помощью расчета коэсфициента корреляции по Пирсону. Статистическая обработка проведена с использованием Microsoft Excel.

Результаты и обсуждение. В статье рассматривается возможность и допустимость использования результатов ВНО для выявления поступающих, которые смогут успешно продолжить обучение в высшей школе. Предложено математически обоснованные рекомендации по повышению качества конкурсного отбора для выявления поступающих и их потенциала относительно обучения. Рекомендации основаны на статистическом анализе данных об успеваемости соискателей высшего образования первого курса обучения специальности 226 «Фармация» отрасли знаний «Здравоохранение», вступивших в Национальный фрармацевтический университет (НФаУ) в

ISSN 2312-0967. Pharmaceutical review. 2017. № 4 
Фармацевтична освіта

Pharmaceutical education

2015 году в сравнении с конкурсным баллом. Доказано, что целенаправленно изменяя весовые коэфрфициенты, используемые при расчете конкурсного балла, вуз может положительно влиять на качественный состав соискателей высшего образования. Получены значения весовых коэффрициентов, при которых достигается максимальная валидность конкурсного отбора.

Выводы. По результатам исследования установлено силу корреляционной связи между конкурсным баллом поступающего и текущей успеваемостью соискателя высшего образования во время первого и второго семестров обучения.

Ключевые слова: прогностическая валидность; конкурсный балл; результаты ВНО; предиктор успешности; поступающий; соискатель высшего образования.

\title{
STUDY OF THE INFLUENCE OF EMPLOYED COEFFICIENTS ON PROGNOSTIC DURATION OF THE COMPETITIVE BALANCE OF HEALTH DEVELOPMENT PARTICIPANTS
}

\author{
A. A. Kotvitskaya, N. V. Zhivora, S. V. Pogorelov, I. V. Krasovsky, O. A. Vislous \\ National University of Pharmacy, Kharkiv \\ socpharm@nuph.edu.ua
}

The aim of the work. Studying the influence of weight coefficients on the prognostic validity of the competition score; by means of mathematical substantiation the optimal values of these coefficients are determined, which will ensure the maximum validity of competitive selection.

Materials and Methods. The study of the success of higher education students of the first year of full-time education by specialty 226 «Pharmacy» was conducted.

The estimation of the linear interconnection power between the competition score (and its components) and the indicators of the current success of higher education was obtained by calculating the Pearson correlation coefficient. Statistical processing is done using Microsoft Excel.

Results and Discussion. The article examines the possibility and feasibility of using the results of external testing to identify entrants who can successfully continue their studies at a higher school. The mathematically based recommendations for improving the quality of competitive selection for identifying entrants who will be able to successfully study at higher educational institutions are offered. The recommendations are based on a statistical analysis of the data on the success of higher education students of the first year of specialization 226 «Pharmacy» in the field of knowledge «Health», entered the National Pharmaceutical University (NUPh) in 2015 in comparison with the competition point. It has been proved that by purposefully changing the weighting factors used in the calculation of the competition, the university can positively influence the qualitative composition of higher education graduates. The value of weight coefficients, at which the maximum validity of competitive selection is achieved, is obtained.

Conclusions. According to the results of the study, the correlation between the competition score of the student and the current achievement of the applicant of higher education during the first and second semester of the study was established.

Key words: prognostic validity; competition score; outcomes results; predictor of success; admission; student of higher education.

\section{Список літератури}

1. Кашина Г. С. Зовнішнє незалежне оцінювання в освіті України. Курс лекцій : навч. посіб. / Г. С. Кашина, В. П. Сергієнко. - Луцьк, 2010. - 15 с.

2. Хавенсон Т. Е. Связь результатов Единого государственного экзамена и успеваемости в вузе / Т. Е. Хавенсон, А. А. Соловьева // Вопросы образования. - 2014 - № 1. - С. 176-199.

3. Світовий досвід НСТ. - http://www.timo.com.ua/ node/7930.

4. Система відбору до ВН3. - http://www.timo.com.ua/ node/588.

5. Дослідження якості конкурсного відбору здобувачів вищої освіти вищих навчальних закладів за результатами зовнішнього незалежного оцінювання: аналітичні матеріали / За редакцією В. В. Ковтунця і С. А. Ракова.
- К.: Нора-Друк, 2015. - 160 с.

6. Польдин О. В. Прогнозирование успеваемости в вузе по результатам ЕГЭ / О. В. Польдин // Прикладная эконометрика. - 2011. - № 1. - С. 56-69.

7. Влияние исходного уровня знаний абитуриентов на успешность обучения в медицинском вузе / А. В. Лысенкова, В. А. Филиппова, Л. В. Чернышева [и др.] // Проблемы здоровья и экологии. - 2011. - № 1 (27). C. 41-48.

8. Validity of the SAT for predicting first-year college grade point average / J. L. Kobrin, B. F. Patterson, E. J. Shaw [et al.] // College Board Research Report. No. 2008-5. N.Y.: The College Board, 2008.

9. Brian F. Validity of the SAT for predicting first-year grades: 2011 SAT validity sample / F. Brian, D. Krista. - 2013. - 16 p.

ISSN 2312-0967. Фармацевтичний часопис. 2017. № 4 
10. Sawyer R. Usefulness of high school average and ACT scores in making college admission dDecisions // ACT Research Report Series No. 2. - 2010.

\section{References}

1. Kashina GS, Sergienko VP. External independent assessment in Ukrainian education. [Зовнішнє незалежне оцінювання в освіті України. Курс лекцій: навч. посіб.] Lutsk; 2010. Ukrainian.

2. Havenson TE, Solovyov AA. [Unified state exam and academic achievement]. Vopr. obraz. 2014;1: 176-99. Russian. 3. World experience of NST http://www.timo.com.ua/ node/7930

4. University selection system http://www.timo.com.ua/ node/588

5. Kovtunets VV, Rakova SA. Investigation of the quality of competitive selection of higher education graduates of higher education institutions based on the results of external independent evaluation: analytical materials. [Дослідження якості конкурсного відбору здобувачів вищої освіти вищих навчальних закладів за результатами зовнішнього незалежного оцінювання: аналітичні матеріали] Kyіv:
11. Kuncel N. R. Standardized Tests Predict Graduate Students Success / N. R. Kuncel, S. A. Hezlett // Science. Vol. 315. - 2007. - No. 5815. - P. 1080-1081.

Nora druk 2015. Ukrainian.

6. Poldin OV. [Forecasting academic performance in the university by the results of USE]. Priklad. ekonometrika. 2011;1: 56-69. Russian.

7. Lysenkova AV. [Influence of the initial level of knowledge of applicants on the success of training in a medical school]. Probl. zdorov. i ekol. 2011;1(27): 41-8. Russian.

8. Kobrin JL, Patterson BF, Shaw EJ et al. Validity of the SAT for predicting first-year college grade point average. College Board Research Report. 2008;5.

9. Brian F, Krista D. Validity of the SAT for predicting firstyear grades: 2011 SAT validity sample. 2013;16.

10. Sawyer R. Usefulness of high school average and ACT scores in making college admission decisions. ACT Research Report Series. 2010;2.

11. Kuncel NR, Hezlett SA. Standardized tests predict graduate students success. Science. 2007;315(5815): 1080-1.

Отримано 14.11.2017 